\title{
The zone without carbon in alloy layer obtained on steel cast
}

Jan Szajnar, Agnieszka Walasek, Czesław Baron

Faculty of Mechanical Engineering, Department of Foundry, Silesian University of Technology ul. Towarowa 7, 44100 Gliwice, Poland. agnieszka.walasek@polsl.pl

In the submitted article are presented the results of researches on the steel cast with surface alloy layer in this article. The simulation of the disintegration of the elements in the place where two materials were in contact was done in order to observe the effects between them. The temperature, the thickness of the layer, micro hardness and the structure were thoroughly examined. The researches were conducted to examine the zone without carbon forming in the joint of two materials. The influence of pouring temperature, the thickness of the cast wall and the size of pad grain on the zone without carbon forming process were also examined. It was also proposed to base the process of the zone out of carbon forming on the work of chromium carbides forming process.

Keywords: composite layer, ferrochromium, cast, mechanism of creation, the zone without carbon

\section{References}

[1] BARTOCHA, D., JANERKA, K., SUCHOŃ., J. (2005). Charge materials and technology of melt and structure of gray cast iron, Archives of Metallurgy and Materials., Vol. 162, Special Issue, pp. $465-470$.

[1] STUDNICKI, A., JEZIERSKI, J. (2012). Stereolgical parametrs of carbides in modified wear resistant Fe-C-Cr alloy, Metal 2012, Internatinal Conderence on Metallurgy and Materials, Brno.

[2] WRÓBEL, T. (2011). Bimetallic layered castings alloy steel - grey cast iron, Archives of Materials Science and Engineering, Vol. 48, No. 2, pp. $118-125$.

[3] CHOLEWA, M., WRÓBEL, T., TENEROWICZ, S., SZUTER, T. (2010). Diffusion phenomena between alloy steel and gray cast iron in layered bimetallic casting. Archives of Metallurgy and Materials, Vol. 55, №. 3, pp. $9-15$.

[4] SZAJNAR, J., BARTOCHA, D., BARON, C., WALASEK, A. (2008). The attempt of determination of parameters for the alloy layer forming process based on the empirical examination, Archives of Foundry Engineering, Vol. 8, Special Issue 3, pp. 139 - 143.

[5] WRÓBEL, P. (2004).. Improvement of the cast steel castings surface by creating the alloy composite layer in casting process, Doctor's thesis, pp. $4-20$. Silesian University of Technology, Gliwice.

[6] BARON, C. (2007). The surface composite layer on the steel cast, Doctor's thesis, pp. $4-22$. Silesian University of Technology, Gliwice.

[7] WALASEK, A. (2012). Designing of the structure and properties of the alloyed surface layer on the cast steel castings, Doctor's thesis, pp. 4 -30 . Silesian University of Technology, Gliwice.

[8] WRÓBEL, T. (2011). Ni and Cr base layers in bimetallic castings, Metal 2011: International Conference on Metallurgy and Materials. Brno, pp. $758-764$.

[9] BROŽEK, M. (2005). Abrasive wear resistance of selected hardfacing materials, Manufacturing Technology Vol. V. pp. 5 - 9.

[10] KOVAČ, I., ŽARNOVSKY, J., DRLIČKA, R., RUŽBARSKY, J. (2010). An improvement of tribological properties of boron alloyed layers, Manufacturing Technology Vol. X. pp. $78-80$.

[11] FRAŚ, E., KAWALEC, M., LOPEZ, H.F. (2009). Solidification microstructures and mechanical properties of high-vanadium Fe-C-V and Fe-C-V-Si alloys, Materials Science and Engineering, Vol. 524 (1-2), pp. 193-203.

[12] WOŁCZYŃSKI, W., OKANE, T., SENDEROWSKI, C., KANIA, B., ZASADA, D., JANCZAK-RUSCH, J. (2011)., Meta-stable conditions of diffusion brazing, Archives of Metallurgy and Materials, Vol. 56 (2), pp. 311-324.

[13] WOŁCZYŃSKI, W. (2006)., Transition phenomena in the diffusion soldering / brazing, Archives of Metallurgy and Materials, Vol. 51 (4), pp. 609-615.

[14] JANERKA, K., BARTOCHA, D., SZAJNAR, J., JEZIERSKI, J. (2010). The carburizer influence on the crystallization process and the microstructure of synthetic cast iron, Archives of Metallurgy and Materials, Vol. 55, issue 3, pp. 851-859.

[15] JANERKA, K., JEZIERSKI, J., BARTOCHA, D., SZAJNAR, J. (2013). Heredity of the structure and properties of gray cast iron melted on a basis of steel scrap, Advanced Materials Research, Vol. 622-623, pp. 685-689.

[16] JANERKA, K., BARTOCHA, D., JEZIERSKI, J., SZAJNAR, J. (2012) Heat Up and Dissolution of Carburizers in Liquid Ferrous Alloys, Metal 2012; International Conference on Metallurgy and Materials, Brno. 